\title{
IN VITRO HEPATOPROTECTIVE EFFECT OF ECHINOCHLOA COLONA ON ETHANOL-INDUCED OXIDATIVE DAMAGE IN HEPG2 CELLS
}

\author{
PRANEETHA P*, DURGAIAH G, NARSIMHA REDDY Y, RAVI KUMAR B
}

\begin{abstract}
Department of Pharmacognosy and Phytochemistry, University College of Pharmaceutical Sciences, Kakatiya University, Warangal - 506 009, Telangana, India. Email: praneetha.sruthi@gmail.com
\end{abstract}

Received: 21 April 2017, Revised and Accepted: 30 May 2017

\section{ABSTRACT}

Objective: The current study was aimed to evaluate the methanolic extract of caryopses of Echinochloa colona (ECME) for its in vitro hepatoprotective activity against ethanol in HepG2 cell lines.

Methods: In this regard, the cytotoxicity studies were conducted for the extract, ECME using 3-(4,5-dimethythiazol- 2-yl)-2,5-diphenyl tetrazolium bromide assay to determine the inhibitory concentration $50 \%$ value based on which, the doses 50,100 , and $200 \mu \mathrm{g} / \mathrm{ml}$ were selected for the hepatoprotective studies in HepG2 cell lines. The toxicity was induced using ethanol (100 mM). The in vitro hepatoprotective activity of the extract was assessed based on the changes in the level of biochemical parameters such as aspartate aminotransferase, alanine aminotransferase, and lactate dehydrogenase.

Results: The extract, ECME has shown a dose-dependent cytoprotective activity with maximum protection at $200 \mu \mathrm{g} / \mathrm{ml}$. The percentage cell viability of the extract, ECME at $200 \mu \mathrm{g} / \mathrm{ml}$ was more, i.e., $69.33 \%$ which was well comparable to that of standard drug, silymarin (100 $\mu \mathrm{g} / \mathrm{ml})$.

Conclusion: The study revealed that the extract had shown significant hepatoprotective activity at all the test doses against ethanol-induced cytotoxity assay.

Keywords: Ethanol, HepG2, Hepatoprotective activity, Echinochloa colona, 3-(4,5-dimethythiazol- 2-yl)-2,5-diphenyl tetrazolium bromide.

(C) 2017 The Authors. Published by Innovare Academic Sciences Pvt Ltd. This is an open access article under the CC BY license (http://creativecommons. org/licenses/by/4. 0/) DOI: http://dx.doi.org/10.22159/ajpcr.2017.v10i9.19322

\section{INTRODUCTION}

Liver disorders are recognized as one of the serious global health problems occurring due to the adoption of modern food styles as well as exposure to many environmental pollutants and excessive intake of some drugs. According to the World Health Organization, liver cirrhosis is the $8^{\text {th }}$ leading cause of death in the United States and $13^{\text {th }}$ leading cause of death globally, with worldwide mortality having increased by 45.6\% from 1990 to 2013 due to alcohol-induced liver cirrhosis [1]. The studies in animal models suggest that liver injury in chronic alcoholics is due to oxidative stress that leads to fibrosis and impaired liver functions and increased apoptosis [2]. Herbal medicines are believed to be much safer and proved elixir in the treatment of various ailments such as diabetes, liver disorders, central nervous system, and disorders [3]. It is estimated that about $80 \%$ of the population of developing countries relies on traditional medicines, mostly plant drugs and for their primary health-care needs [4]. In India, more than 93 medicinal plants are used in different combinations in the preparations of 40 patented herbal formulations. However, only a small proportion of hepatoprotective plants used in traditional medicine are pharmacologically evaluated for their safety and efficacy, and many are yet to be investigated [5]. Hence, there is a great need for identification of such plants for scientific pharmacological investigation.

The plant Echinochloa colona of family Graminae, is significant medicinally and claimed to be useful in the treatment of various ailments such as fever, diabetes, and jaundice. There are no reports on the scientific validation of its traditional medicinal claim. In view of this, an attempt has been made in the present investigation to develop an herbal drug in the treatment of liver disorders. Therefore, the present study was designed to evaluate its traditional claim in the treatment of liver disorders using HepG2 cell lines in vitro.
HepG2 cells are a suitable in vitro model system for the study of human liver diseases that are caused by xenobiotic metabolism and other chemicals that cause toxicity to liver [6]. The objective of the present work is to investigate the methanolic extract of caryopses of E. colona (ECME) for its in vitro hepatoprotective activity against ethanol using HepG2 cell lines.

\section{METHODS}

\section{Collection and preparation of extracts}

The caryopses of E. colona were collected in the month of July 2012, from rice fields of Pedda Pendial, Warangal district, Telangana state, India, after its authentication by Prof. V.S. Raju, Department of Botany, Kakatiya University, Warangal. The material was washed under tap water and shade dried, coarsely powdered (800 g) and macerated with methanol in a round bottom flask for 7 days with intermittent stirring and filtered after 7 days and concentrated under reduced pressure to yield a green semi-solid mass. The percentage yield of the extract was found to be $5.8 \%$.

\section{Drugs and chemicals}

HepG2 Cell lines were obtained from National Centre for Cell Sciences, Pune India. The drugs and chemicals were purchased from various companies and the details are as follows: Dulbecco's modified eagles medium, silymarin - Sigma Aldrich, Spruce Street, St. Louis, China; FC reagent, Biochemical kits - Merck Specialties Private Limited, Mumbai, India; fetal bovine serum was purchased from Himedia laboratories, Mumbai, India; Ethanol - Changshu Yangyuan Chemicals, China. All other chemicals and solvents used were of analytical grade.

\section{Phytochemical analysis}

The ECME was subjected to chemical tests for detection of various phytoconstituents such as saponins, steroid/triterpenoidal, flavonoidal compounds and their glycosides, alkaloids, phenolics, and tannins [7] 
Determination of total phenolic content

The total phenolic content in ECME was determined using Folin-Ciocalteu reagent according to the method of Marinova et al. [8] with minor modifications. It was carried out in triplicate and expressed as gallic acid equivalents in mg per gram of extract.

\section{Determination of total flavonoid content}

The total flavonoid content in ECME was determined using aluminium chloride assay following the method of Marinova et al. [8] and was performed in triplicate and expressed as rutin equivalents (RE) in mg per gram of extract.

\section{Determination of in vitro cytotoxic activity}

The 50\% cytotoxic concentration CTC 50 was determined by estimating mitochondrial synthesis using tetrazolium assay [9]. HepG2 cells $\left(5.0 \times 10^{3}\right.$ cells/well $)$ were maintained in 96 well culture plate for $72 \mathrm{hrs}$ in presence of $100 \mu \mathrm{l}$ of ECME at the concentrations of $10,30,100,300,1000$, and $3000 \mu \mathrm{g} / \mathrm{ml}$. At the end of incubation period, the drug solutions in the wells were discarded and $50 \mu \mathrm{l}$ of 3-(4,5-dimethythiazol- 2-yl)-2,5-diphenyl tetrazolium bromide (MTT) prepared in modified Eagle's medium (MEM) without phenol red was added in each well. The plates were gently shaken and incubated for $3 \mathrm{hrs}$ at $37^{\circ} \mathrm{C}$ in $5 \% \mathrm{CO}_{2}$ atmosphere. After $3 \mathrm{hrs}$, the supernatant was removed. Later on, $50 \mu$ l of propanol was added, and the plates were gently shaken to solubilize the formed formazan followed by $30 \mathrm{~min}$ incubation at room temperature with constant shaking. Absorbance (optical density [OD]) was read at $540 \mathrm{~nm}$ using microplate reader (BioTek Instruments, Inc., Winooski, VT). The percentage growth inhibition was calculated using the following formula:

$\%$ Growth inhibition $=($ Mean OD of normal control - Mean OD of test group/Mean OD of Normal control) $\times 100$

A dose-response curve was generated using \% growth inhibition on $\mathrm{Y}$ axis and the extract concentration $(\mu \mathrm{g} / \mathrm{ml})$ on X-axis. The CTC 50 value is calculated from dose-response curve.

\section{Assessment of hepatoprotective activity of ECME in vitro}

The hepatoprotective activity of ECME was evaluated using wellmaintained HepG2 cells. Ethanol was used as hepatotoxicant and silymarin was used as a standard positive control. The toxic concentration of ethanol taken was $100 \mathrm{mM}$. The choice of concentrations of ECME and standard was based on the results of the MTT assay. The experimental groups were carried out in triplicate as follows:

1. Group I (Control):

- Normal control: The cells were treated with $100 \mu \mathrm{l}$ of serum-free culture medium for $24 \mathrm{hrs}$.

- Dimethyl sulfoxide (DMSO) control: The cells were treated with $100 \mu \mathrm{l}$ of serum-free culture medium containing DMSO $(0.3 \% \mathrm{v} / \mathrm{v})$ for $24 \mathrm{hrs}$.
- Silymarin control: The cells were treated with $100 \mu \mathrm{l}$ of serumfree culture medium containing silymarin $(200 \mu \mathrm{g} / \mathrm{ml})$ for $24 \mathrm{hrs}$.

- $\quad$ ECME control: The cells were treated with $100 \mu \mathrm{l}$ of serum-free culture medium containing ECME $(200 \mu \mathrm{g} / \mathrm{ml})$ for $24 \mathrm{hrs}$.

2. Group II (toxin treatment): The cells were treated with $100 \mu \mathrm{l}$ of serum-free culture medium containing $100 \mathrm{mM}$ ethanol for $24 \mathrm{hrs}$.

3. Group III (silymarin treatment): The cells were treated with $100 \mu \mathrm{l}$ of serum-free culture medium containing $100 \mathrm{mM}$ ethanol with silymarin at a concentration of 50 and $100 \mu \mathrm{g} / \mathrm{ml}$ for $24 \mathrm{hrs}$.

4. Group IV (ECME treatment): The cells were treated with $100 \mu \mathrm{l}$ of serum-free culture medium containing $100 \mathrm{mM}$ ethanol with ECME at a concentration of 50,100 , and $200 \mu \mathrm{g} / \mathrm{ml}$ for $24 \mathrm{hrs}$. Later, cell viability, aspartate aminotransferase (AST), alanine aminotransferase (ALT), and lactate dehydrogenase (LDH) leakage assays were performed for all groups according to the standard method [6] using Ecoline diagnostic kits.

\section{Statistical analysis}

The data obtained were analyzed by one-way ANOVA followed by Dunnett's multiple comparisons test using the Graph pad prism version 4 (Graph Pad Software, La Jolla California USA).

\section{RESULTS AND DISCUSSION}

It is well known that plants or their extracts contain a number of chemicals belonging to different classes. Most of them are of pharmacological importance such as flavonoids, steroids, triterpenoids, and their glycosides, alkaloids [10]. Hence, preliminary phytochemical screening of the extract, ECME was carried out. The preliminary investigation on the ECME revealed that it contains chemical constituents of pharmacological significance such as steroidal/ triterpenoidal and flavonoidal glycosides, saponins, and phenolic compounds. The flavonoidal and phenolic compounds play an important role in culminating the oxidative stress produced by reactive oxygen species and hydroxyl radicals generated in alcohol metabolism. The total phenolic and flavonoidal content of the extract, ECME was found to be $44.53 \pm 2.11$ and $13.56 \pm 1.29 \mathrm{mg}$ of gallic acid and REs per gram of extract, respectively.

\section{In vitro cytotoxic activity}

The results are shown in Fig. 1. The inhibitory concentration 50\% value of ECME was found to be $2249.87 \mu \mathrm{g} / \mathrm{ml}$. In MTT assay, the cell viability was $>85 \%$ up to a concentration of $1000 \mu \mathrm{g} / \mathrm{ml}$. Therefore, the extract concentrations of 50,100 and $200 \mu \mathrm{g} / \mathrm{ml}$ were selected to further evaluate the cytoprotective activity against ethanol-induced cell damage.

\section{In vitro hepatoprotective activity of the extract, ECME}

The results of the study are shown in Table 1. Ethanol is metabolized by alcohol dehydrogenase in liver. However, in conditions such as extract

Table 1: In vitro hepatoprotective activity of ECME using HepG2 cell lines

\begin{tabular}{|c|c|c|c|c|}
\hline Groups & \%Cell viability & LDH & ALT & AST \\
\hline \multicolumn{5}{|l|}{ Group I (control) } \\
\hline Normal control & $98.51 \pm 1.1$ & $133.33 \pm 4.11^{\mathrm{a}}$ & $8.61 \pm 1.14^{\mathrm{a}}$ & $11.61 \pm 1.03^{\mathrm{a}}$ \\
\hline DMSO control $(0.1 \% \mathrm{v} / \mathrm{v})$ & $95.61 \pm 1.04$ & $141.11 \pm 3.34^{\mathrm{a}}$ & $9.33 \pm 1.24^{\mathrm{a}}$ & $13.14 \pm 1.02^{\mathrm{a}}$ \\
\hline Silymarin control $(100 \mu \mathrm{g} / \mathrm{ml})$ & $97.24 \pm 1.02$ & $138.36 \pm 4.16^{\mathrm{a}}$ & $8.93 \pm 1.25^{\mathrm{a}}$ & $12.18 \pm 1.11^{\mathrm{a}}$ \\
\hline ECME control $(200 \mu \mathrm{g} / \mathrm{ml})$ & $96.11 \pm 1.08$ & $140.31 \pm 3.76^{\mathrm{a}}$ & $9.12 \pm 2.11^{\mathrm{a}}$ & $13.06 \pm 1.24^{\mathrm{a}}$ \\
\hline \multicolumn{5}{|l|}{ Group II (toxin treatment) } \\
\hline $100 \mathrm{mM}$ ethanol & $31.27 \pm 1.02^{\mathrm{a}}$ & $230.6 \pm 5.42^{\mathrm{a}}$ & $36.38 \pm 2.15^{\mathrm{a}}$ & $49.31 \pm 2.54^{\mathrm{a}}$ \\
\hline $100 \mathrm{mM}$ ethanol + silymarin $(50 \mu \mathrm{g} / \mathrm{ml})$ & $78.31 \pm 1.81^{\mathrm{a}}$ & $156.31 \pm 3.16^{\mathrm{a}}$ & $15.17 \pm 2.14^{\mathrm{a}}$ & $20.14 \pm 2.17^{\mathrm{a}}$ \\
\hline $100 \mathrm{mM}$ ethanol + silymarin $(100 \mu \mathrm{g} / \mathrm{ml})$ & $86.72 \pm 1.35^{\mathrm{a}}$ & $144.23 \pm 4.32^{\mathrm{a}}$ & $13.31 \pm 1.19^{\mathrm{a}}$ & $18.36 \pm 1.33^{\mathrm{a}}$ \\
\hline \multicolumn{5}{|l|}{ Group IV (ECME treatment) } \\
\hline $100 \mathrm{mM}$ ethanol + ECME $(50 \mu \mathrm{g} / \mathrm{ml})$ & $52.15 \pm 1.01^{\mathrm{a}}$ & $199.3 \pm 1.26^{\mathrm{a}}$ & $29.61 \pm 2.35^{\mathrm{a}}$ & $34.31 \pm 1.27^{\mathrm{a}}$ \\
\hline $100 \mathrm{mM}$ ethanol + ECME $(100 \mu \mathrm{g} / \mathrm{ml})$ & $60.16 \pm 1.52^{\mathrm{a}}$ & $188.21 \pm 3.14^{\mathrm{a}}$ & $25.64 \pm 2.31^{\mathrm{a}}$ & $27.34 \pm 2.05^{\mathrm{a}}$ \\
\hline $100 \mathrm{mM}$ ethanol + ECME $(200 \mu \mathrm{g} / \mathrm{ml})$ & $69.33 \pm 2.03^{\mathrm{a}}$ & $179.24 \pm 4.43^{\mathrm{a}}$ & $20.4 \pm 2.18^{\mathrm{a}}$ & $24.36 \pm 2.67^{\mathrm{a}}$ \\
\hline
\end{tabular}

Data represent mean \pm SD ( $\mathrm{n}=6$ ). $\mathrm{p}$ value - Normal versus other groups; ${ }^{\mathrm{a}} \mathrm{p}<0.01,{ }^{\mathrm{b}} \mathrm{p}<0.05$. ECME: Methanolic extract of Echinochloa colona, SD: Standard deviation,

AST: Aspartate aminotransferase, ALT: Alanine aminotransferase, LDH: Lactate dehydrogenase, DMSO: Dimethyl sulfoxide 


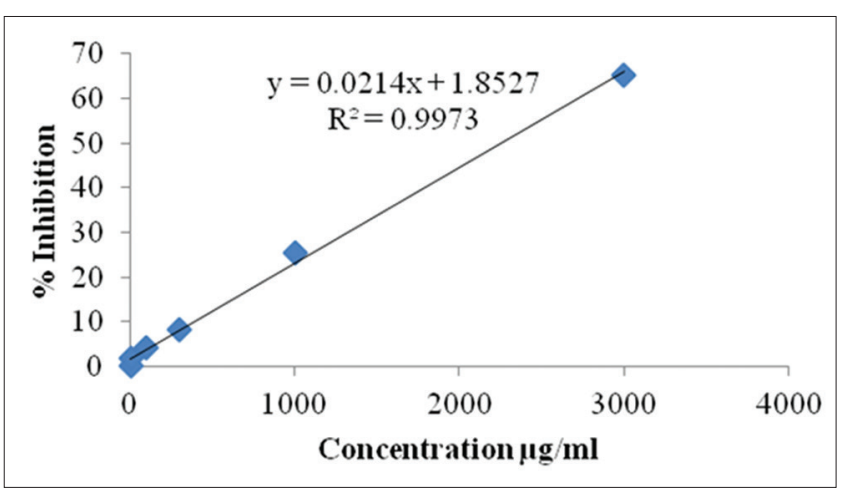

Fig. 1: In vitro cytotoxic activity of methanolic extract of Echinochloa colona

have some functions in preserving the structural integrity of cellular membrane alcohol abuse, the microsomal electron transport system also participates in ethanol oxidation through cytochrome P 450 (2E1, 1A2, and 3A4 isoforms) isoenzyme, which generates free radicals causing cell damage [11]. Treatment with ethanol $(100 \mathrm{mM})$, alone caused a drastic decrease in cell viability, i.e., $31.27 \pm 1.02 \%$ viability. Inoculation of ethanol increased the levels of AST, ALT, and LDH indicating damage to the cell plasma membrane as these enzymes are normally present in cytoplasm [12]. Treatment with ECME at 50, 100, and $200 \mu \mathrm{g} / \mathrm{ml}$ significantly reduced the elevated level of these enzymes in ethanol treated rats. This reflects that the extract have some functions in preserving structural integrity of hepatocellular membrane thus prevented the leakage of enzymes. The extract, ECME has shown a dose-dependent cytoprotective activity with maximum protection at $200 \mu \mathrm{g} / \mathrm{ml}$.

\section{CONCLUSION}

The reason behind the protective effect of extract may be due to its ability to scavenge-free radicals that are produced during the metabolism of ethanol in HepG2 cells. The antioxidant principles such as flavonoids and phenolic compounds present in the extract, ECME contribute to the hepatoprotective activity of the extract. Further, the findings of the study substantiate the usage of the plant in traditional medicine for the treatment of jaundice.

\section{ACKNOWLEDGMENTS}

This work was supported by a grant (UGC sanction No.F.7-106/2007 (BSR), dated January 16, 2012) from UGC-BSR Meritorious Research Fellowship, New Delhi.

\section{REFERENCES}

1. Ge PS, Runyon BA. Treatment of patients with cirrhosis. N Engl J Med 2016;375(8):767-77.

2. Habib-ur-Rehman M, Tahir M, Lone KP, Sami W. Ethanol induced hepatotoxicity in albino rats. J Coll Physicians Surg Pak 2011(10);21:642-3

3. Ranjith $\mathrm{AA}$, Ilango $\mathrm{K}$, Vishwanath $\mathrm{AB}$, Ganeshan $\mathrm{S}$. In-vitro hepatoprotective activity of extracts of Viburnum punctatum buch-ham Ex d.Don against carbon tetrachloride induced toxicity. Int J Pharm Pharm Sci 2014;6(7):392-4.

4. Anil K. Manju OP, Nishant R. In-vitro hepatoprotective activity of Albizia lebbeck, Cassia occidentalis and Swertia chirata on HepG2 cells. Asian J Pharm Clin Res 2016;9(4):276-80

5. Vilas AA, Supriya RW, Rahul VM. Hepatoprotective activity of livergen, a polyherbal formulation against carbon tetrachloride induced hepatotoxicity in rats. Int $\mathrm{J}$ Pharm Pharm Sci 2011;3(3):228-31.

6. Ihrke G, Neufeld EB, Meads T, Shanks MR, Cassio D, Laurent M, et al. WIF-B cells: An in vitro model for studies of hepatocyte polarity. J Cell Biol 1993;123(6 Pt 2):1761-75.

7. Kokate CK, Purohit AP, Gokhale SB. Analytical pharmacognosy: Phytochemical investigations. $5^{\text {th }}$ ed. India: Nirali Prakashan; 1997.

8. Marinova D, Ribarova F, Atanassova M. Total phenolics and total flavonoids in Bulgarian fruits and vegetables. J Univ Chem Tech Metall 2005;40(3):255-60.

9. Pareek A, Godavarthi A, Issarani R, Nagori BP. Antioxidant and hepatoprotective activity of Fagonia schweinfurthii (Hadidi) Hadidi extract in carbon tetrachloride induced hepatotoxicity in HepG2 cell line and rats. J Ethnopharmacol 2013;150(3):973-81.

10. Divya B, Praneetha P, Swaroopa Rani V, Ravi Kumar B. Hepatoprotective effect of whole plant extract fractions of Marsilea minuta Linn. Asian J Pharm Clin Res 2013;6(3):100-7.

11. Tome S, Lucey MR. Review article: Current management of alcoholic liver disease. Aliment Pharmacol Ther 2004;19(7):707-14.

12. Praneetha P, Swaroopa Rani V, Narsimha Reddy Y, Ravi Kumar B. Hepatoprotective studies on methanolic extract of whole plant of Lindernia ciliata. Bangladesh J Pharmacol 2014;9:567-74. 